\title{
Parturition time for the Blacktip shark, Carcharhinus limbatus (Carcharhiniformes: Carcharhinidae), ə in Southwestern Atlantic
}

\author{
Correspondence: \\ Jones Santander-Neto \\ jones.santander@ifes.edu.br
}

Submitted April 29, 2020

Accepted September 1, 2020

by Lisa Whitenack

Epub October 09, 2020

\author{
${ }^{\oplus}$ Jones Santander-Neto ${ }^{1},{ }^{\oplus}$ Leandro Yokota ${ }^{2}$ and \\ ${ }^{\top}$ Thiago Silveira de Meneses ${ }^{3}$
}

The determination of the period of parturition and identification of nursery areas are fundamental for the management and conservation of a fishing resource. Through combination of monthly abundance, length measurements, and development time of embryos we inferred about parturition time of the Blacktip sharks, Carcharhinus limbatus, from Southwestern Atlantic. Specimens of C. limbatus were caught from 2002 and 2008 by artisanal fleets from three different locations along the Brazilian coast using gillnets (mesh width ranging between 30 and $120 \mathrm{~mm}$ between opposite knots and operating from 9 to $120 \mathrm{~m}$ in depth), handlines (19 to $140 \mathrm{~m}$ depth) and longlines (6 to $90 \mathrm{~m}$ depth). Through a comparative analysis of fisheries landing data collected, we have verified neonatal $(<90 \mathrm{~cm})$ catch peaks at specific times of the year in different locations and, matching with birth prediction of embryos, propose that C. limbatus presents a well-defined parturition time in late spring-early summer in Southwestern Atlantic. Moreover, we indicate supposed nursery grounds for the species along the Brazilian coast. This information will be crucial for stock assessments of the species and may serve as a basis for determining fisheries management measures.

Keywords: Birth time, Chondrichthyes, Fishery, Nursery, Reproductive biology.
Online version ISSN 1982-0224 Print version ISSN 1679-6225

Neotrop. Ichthyol.

vol. 18, no. 3, Maringá 2020

\footnotetext{
1 Instituto Federal de Educação, Ciência e Tecnologia do Espírito Santo, Campus Piúma, Rua Augusto Costa de Oliveira, 660, Praia Doce, 29285-000 Piúma, ES, Brazil. (JSN) jones.santander@ifes.edu.br, (corresponding author).

2 Departamento de Zoologia, Instituto de Biociências, Universidade de São Paulo, Rua do Matão, Trav. 14, no. 101, 05508-900 São Paulo, SP, Brazil. (LY) ly779@hotmail.com.

3 Grupo de Estudo de Elasmobrânquios de Sergipe (GEES). Universidade Tiradentes, Campus Farolândia, Av. Murilo Dantas, 300, Bairro Farolândia, 49032-490 Aracaju, SE, Brazil. (TSM) thiago@uniaoconstrucoes.com.br.
} 
A determinação do período de parto e identificação de áreas de berçário são fundamentais para o manejo e conservação da espécie. Através da combinação de abundância mensal, comprimentos e tempo de desenvolvimento de embriões nós inferimos sobre a época de parto do tubarão galha preta, Carcharhinus limbatus, no Sudoeste Atlântico. Espécimes de C. limbatus foram capturados entre 2002 e 2008 por frotas artesanais de três locais diferentes ao longo da costa brasileira usando redes de emalhar (largura de malha variando entre 30 e $120 \mathrm{~mm}$ entre nós opostos e operando de 9 a $120 \mathrm{~m}$ de profundidade), linhas de mão (19 a 140 $\mathrm{m}$ de profundidade) e espinhel (6 a $90 \mathrm{~m}$ de profundidade). Através de análise comparativa de dados de desembarque pesqueiro, verificamos picos de captura de neonatos $(<90 \mathrm{~cm})$ em períodos específicos do ano em diferentes localidades e, combinando com a previsão de nascimento de embriões, propomos que $C$. limbatus apresenta um período de parto bem definido no final da primavera e início do verão no Sudoeste do Atlântico. Além disto, nós indicamos prováveis áreas de berçário ao longo da costa brasileira. Estas informações serão cruciais para avaliações de estoque da espécie e poderão servir de base para determinação de medidas de manejo de pescarias.

Palavras-chave: Berçário, Biologia reprodutiva, Chondrichthyes, Época de parto, Pesca.

\section{INTRODUCTION}

The Blacktip Shark, Carcharhinus limbatus (Valenciennes, 1839), is a medium-sized species inhabiting the inshore waters from tropical and subtropical seas throughout the world (Burgess, Branstetter, 2009). This species makes use of inshore nursery grounds (e.g. Castro, 1996; Carlson, 2002; Heupel, Hueter, 2002; Hueter, Tyminski, 2002; Heupel et al., 2004; Harry et al., 2012), which makes it more vulnerable to fishing pressure and other anthropogenic impacts. This already was an important commercial and recreational fishery species, with valuable meat and fins (Branstetter, Burgess, 1996, 1997; Hanfee, 1997; Burgess, Branstetter, 2009). Currently, C. limbatus has been assessed globally as "Near Threatened" by the IUCN Red List of Threatened Species (Burgess, Branstetter, 2009).

This shark presents, throughout its cosmopolitan distribution, differences in its population parameters related to reproductive and growth aspects (Branstetter, 1987; Killam, Parsons, 1989; Castro, 1996; Capapé et al., 2004; Carlson, Sulikowski, 2006; Burgess, Branstetter, 2009; Baremore, Passerotti, 2013). Genetic analyses also provide evidence for separate populations in different oceans (Keeney, Heist, 2006; Sodré et al., 2012). Given this well-documented difference in population parameters, it is pertinent that the different populations of C. limbatus be considered as different management units for the purpose of protecting their populations, in regions where these differences have been proven.

The determination of the period of parturition and identification of nursery areas are fundamental for the management and conservation of a fishing resource. The purpose 
of the present study is to infer about the parturition time of C. limbatus in Southwestern Atlantic through a comparative analysis of fishery data collected along the Brazilian coast and indicate possible nursery grounds.

\section{MATERIAL AND METHODS}

Monitoring of fishing landings was conducted as part of a faunal survey on Mucuripe beach, Ceará (CE) State, from November 2006 to June 2008, totaling 102 days of sampling; Caiçara do Norte, Rio Grande do Norte (RN) State, from September 2003 to August 2004 (data from Yokota, Lessa, 2006), totaling 132 days of sampling and; Mosqueiro beach and Aracaju Fishing Terminal, Sergipe (SE) State, from May 2002 to February 2008, totaling 211 days of sampling. In addition to these landing sites in Northeastern Brazil, we compare our data to that found by Bornatowski (2008) in Paraná coast (2539'S; $48^{\circ} 26^{\prime}$ W; Fig. 1).

The sampled fleet from Mucuripe embayment, CE, is composed of motor boats and rafts. The motor boats are vessels with length ranging from 8 to $15 \mathrm{~m}$. These vessels remain from one to five days at sea, with an average of three days. The fishing gear used is gillnets. These nets are approximately $100 \mathrm{~m}$ in length and height ranging from 3 to $5 \mathrm{~m}$, with mesh width ranging between 100 and $120 \mathrm{~mm}$ between opposite knots. Net deployment ranges from 9 to $21 \mathrm{~m}$ depth (Carneiro, Salles, 2011). On the other hand, rafts are sailing vessels with approximate $6 \mathrm{~m}$ of length. These vessels remain three to six days at sea in depths ranging from 19 to $140 \mathrm{~m}$. The fishing gear used is hook and line and the hook size range from 2 to $14 \mathrm{~cm}$ (Freitas, 2000).

The sampled fleet from Caiçara do Norte, RN, is composed of motor boats and rafts (5-12 m). The sharks were caught by gillnets and longlines. Gillnets between 100 and $160 \mathrm{~m}$ in length, with stretched mesh sizes between opposed knots of 30 and $60 \mathrm{~mm}$, were employed by 52 boats, operating from 3 to $120 \mathrm{~m}$ in depth, with the highest fishing effort between 5 and $30 \mathrm{~m}$ in depth. Only two boats employed longlines $(225 \mathrm{~m}$ in length and 85 hooks), fishing between depths of 10 and $90 \mathrm{~m}$.

The sampled fleet from Mosqueiro beach and Aracaju Fishing Terminal, SE, is composed of rafts $(\sim 7 \mathrm{~m})$, with a crew composed of up to three fishermen with autonomy for one day of fishing and operating at depths ranging from 3 to 42 meters. The sharks were captured with gillnet and longline. The nets are from 1,800 to 2,500 $\mathrm{m}$ in length and between 2 and $3 \mathrm{~m}$ in height and mesh size varying between 40 and 90 $\mathrm{mm}$ between opposite knots. The longline was made with a $5 \mathrm{~mm}$ twisted polyethylene multifilament rope as the main cable, nylon $\mathrm{n}^{\circ} 140$ as secondary lines and with about $450 \mathrm{n}^{\circ} 5$ hooks.

The care and use of experimental animals welfare laws are not applied due to data sampling be from commercial fishing landings. The specimens were commercialized by the fishermen and we did not retain it for another purpose. Specimens of Carcharhinus limbatus were measured in total length (TL, in $\mathrm{cm}$ ) and identified by sex. When pregnant females were observed, we expected the fishermen to eviscerate the individuals to record information about the number and TL of embryos.

Neonates of C. limbatus are born with TL approximately between 55 and $65 \mathrm{~cm}$ (Castro, 1993; Dudley, Cliff, 1993; Castro, 1996; Yokota, Lessa, 2006). Considering 


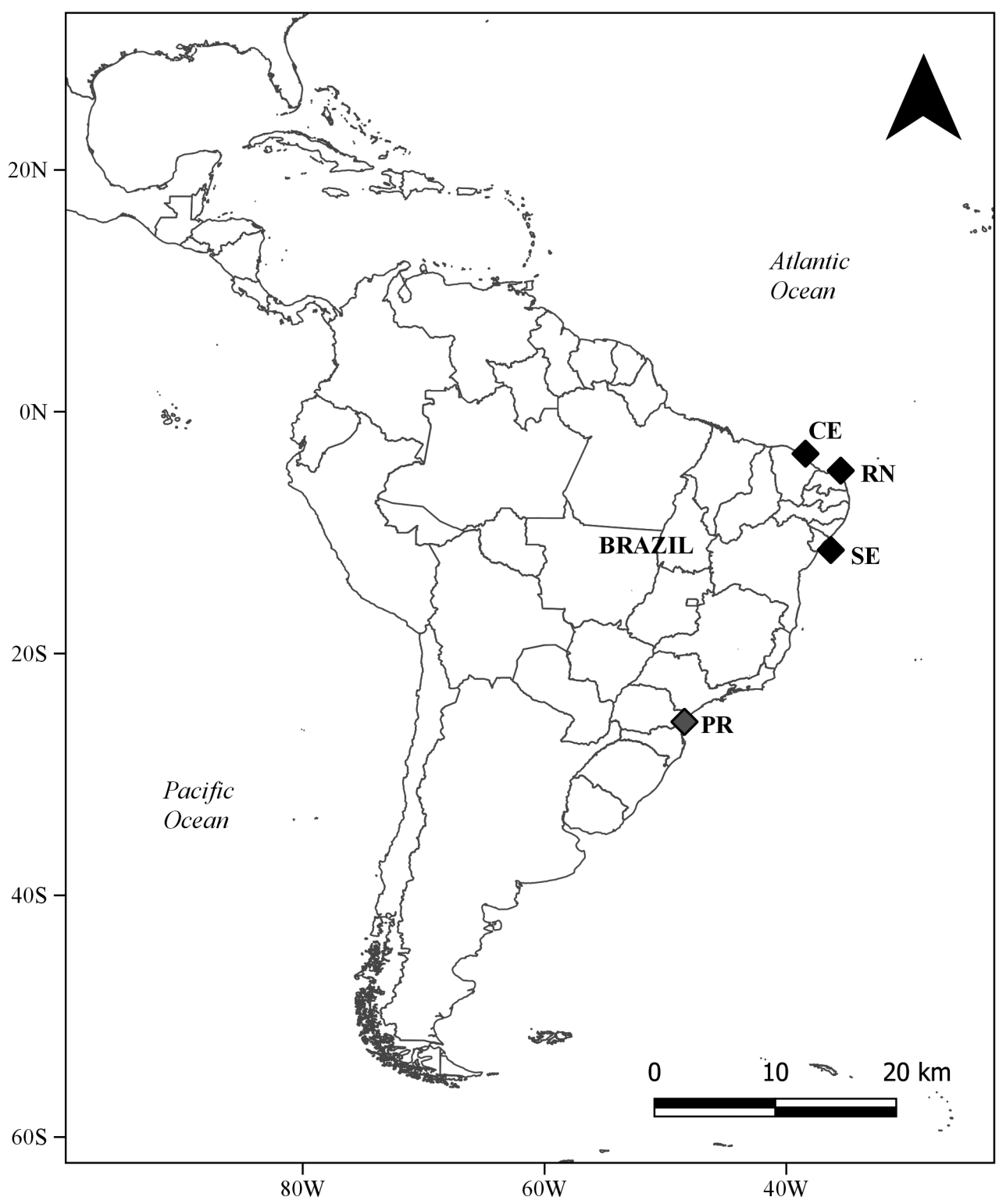

FIGURE 1 I Map displaying the locations in Southwestern Atlantic where the individuals of the Blacktip Shark, Carcharhinus limbatus, were sampled. Black squares: present study; gray square: Bornatowski (2008). Abbreviations: CE, Ceará; RN, Rio Grande do Norte; SE, Sergipe; PR, Paraná.

that the total length of individuals with approximately six months of life is about $30 \mathrm{~cm}$ greater than the birth size (Branstetter, 1987; Castro, 1996), we consider for the next analysis individuals up to $90 \mathrm{~cm}$ as neonates, even understanding that part of them could be considered as young-of-the-year (YOY).

Monthly mean daily abundance (number of individuals divided by days of sampling) and mean TL for neonates was set for each state to evaluate the months with higher abundance of smaller individuals indicating birth period and their mean TL through initial months of life. Significant differences in TL between months for each state were analyzed using Kruskall-Wallis test with a significant level of 0.05 and when differences 
were found Dunn's post-hoc was used.

We extracted data of length-at-development time in days (DTD) of embryos (Castro, 1996; fig. 4, page 515) using the software im2graph (Vaingast, 2014) to create a predictive linear regression for the estimation of DTD of embryos. This linear regression was used for estimating DTD of embryos sampled from gravid females by Yokota, Lessa (2006).

\section{RESULTS}

A total of 190 C. limbatus were sampled, with neonates dominating the catches (170 individuals, 89.47\%) (Fig. 2). Of these individuals, 97.9\% were immature with a predominant distribution in classes close to the birth size for the species.

In Ceará, 98 Carcharhinus limbatus were sampled, with total length ranging between 58 and $195.5 \mathrm{~cm}$ and an average of $77.70 \pm 10.19 \mathrm{~cm}$. The sex ratio was 1 \%: $10^{7}\left(\mathrm{x}^{2}=0.0\right.$; $\mathrm{p}=1.0$ ). Of these individuals, $94.9 \%$ were immature with a predominant distribution in classes close to the birth size for the species (Fig. 2A).

In Rio Grande do Norte, 41 C. limbatus were sampled, with total length ranging between 58.5 and $199 \mathrm{~cm}$ and an average of $81.85 \pm 19.83 \mathrm{~cm}$. The sex ratio was 1.33\%: $10^{\prime \prime}\left(x^{2}=0.457 ; p=0.499\right)$. Of these individuals, $90.24 \%$ were immature with a predominant distribution in classes close to the birth size for the species (Fig. 2B).

In Sergipe, 51 C. limbatus were sampled, with a total length ranging between 59.5 and $108.3 \mathrm{~cm}$ and an average of $68.80 \pm 3.50 \mathrm{~cm}$. The sex ratio was 1.13\%: $10^{7}\left(\mathrm{x}^{2}=\right.$ $0.078 ; \mathrm{p}=0.7794)$. Of these individuals, $100 \%$ were immature with a predominant distribution in classes close to the birth size for the species (Fig. 2C)

In Ceará, it is possible to observe a greater abundance of neonates of C. limbatus between the months of December and January, coinciding with the lowest TL values (Fig. 3A). There were significant differences in TL between the months analyzed ( $\mathrm{H}$ $=39,362$; d.f. $=3 ; \mathrm{p}<0.0001)$. These significant differences were found between the months of December and January $(\mathrm{df}=3 ; \mathrm{Z}=3.0741 ; \mathrm{p}<0.05)$ and January and March $(\mathrm{df}=3 ; \mathrm{Z}=4.3349 ; \mathrm{p}<0.05)$, indicating the beginning of the birth period in the region and subsequent increase in TL of C. limbatus over the months.

In Rio Grande do Norte, it is possible to observe a greater abundance of neonates of C. limbatus in December, coinciding with the lowest TL values (Fig. 3B). However, there was no significant difference in the total length between the months of November and December $(\mathrm{H}=0.2619$; d.f. $=1 ; \mathrm{p}=0.6088)$.

In Sergipe, it is possible to observe a greater abundance of neonates of C. limbatus in January, with the lowest TL values between December and February (Fig. 3C). There were significant differences in TL between the months analyzed $(\mathrm{H}=11.2952$; d.f. $=3$; $p=0.0102)$. These significant differences were found between the months of December and March $(\mathrm{df}=3 ; \mathrm{Z}=3.1025 ; \mathrm{p}<0.05)$ and February and March $(\mathrm{df}=3 ; \mathrm{Z}=2.7075$; $\mathrm{p}<0.05$ ), indicating the beginning of the birth in the region in December and the increase in TL of C. limbatus over the months.

In Ceará, Rio Grande do Norte and Sergipe neonates and individuals close to birth size were basically restricted to late spring and summer (December to March), with the boom of abundance occurring in December and January, coinciding with the smaller TL values (Fig. 3). After this, the abundance of the neonates and small juveniles decreases 
sharply until March-April, when they disappear from coastal waters. At the same time, we can observe a gradual growth in TL from late spring to late summer. The capture of C. limbatus for the rest of the year was occasional.

The calculated equation for development time in days was DTD $=0.4982 \mathrm{TL}(\mathrm{mm})$ + 17.605 $\left(\mathrm{R}^{2}=95.34 \%\right)$. In Caiçara do Norte (RN), the longline (10.5m in depth) caught three gravid females bearing 6-8 embryos ranging from 22.2 to $29 \mathrm{~cm}$ TL in June (Tab. 1). The DTD of the embryos sampled in June was estimated at $144.22 \pm 4.99$ days.
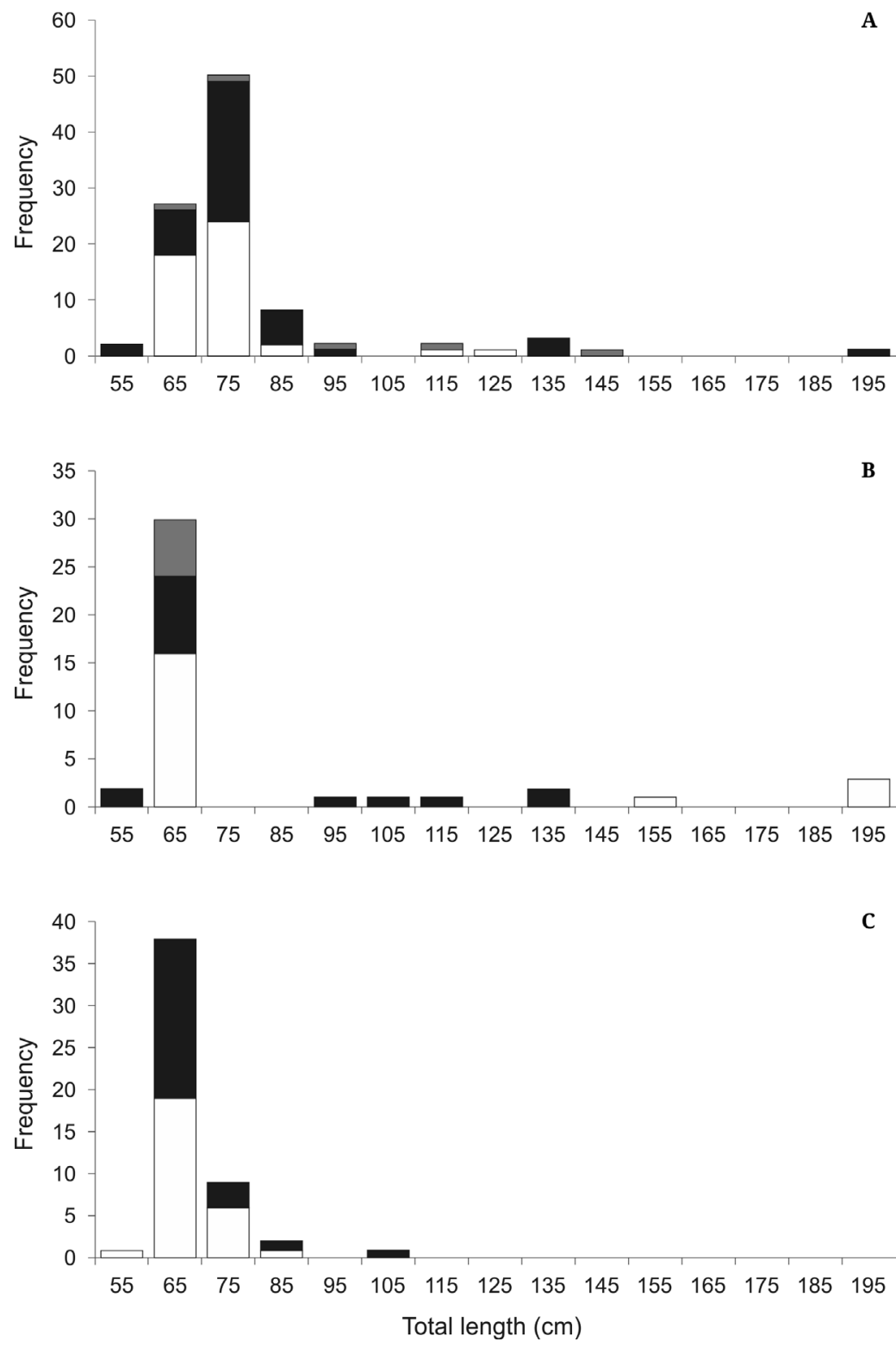

FIGURE 2 I Total Length (TL) frequency for the Blacktip Shark, Carcharhinus limbatus, caught in Northeastern Brazil. A) Ceará; B) Rio Grande do Norte; C) Sergipe. Black bars, males; white bars, females; gray bars, undetermined sex. 
A

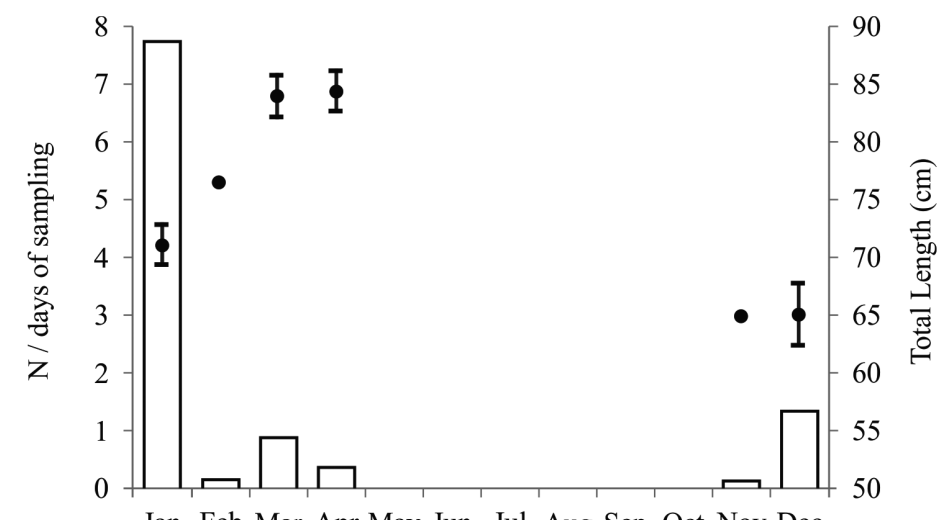

Jan Feb Mar Apr May Jun Jul Aug Sep Oct Nov Dec

B

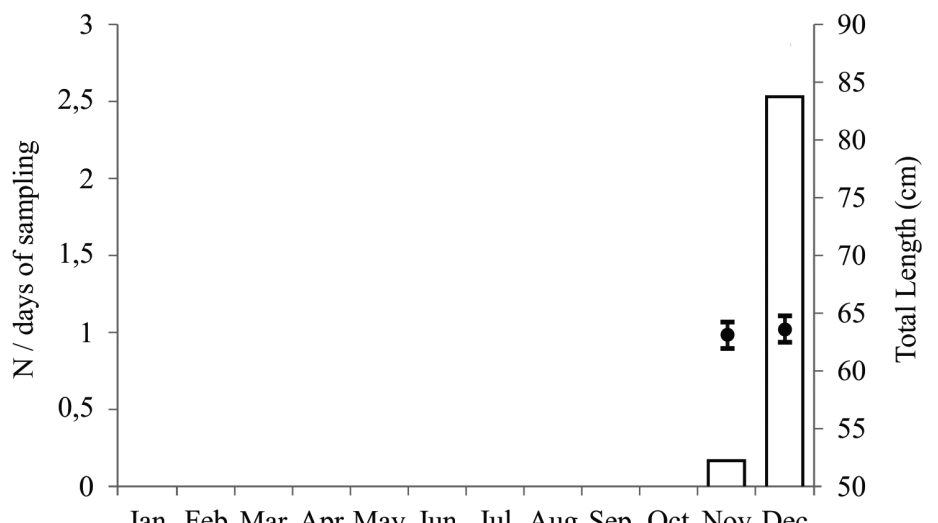

Jan Feb Mar Apr May Jun Jul Aug Sep Oct Nov Dec

C

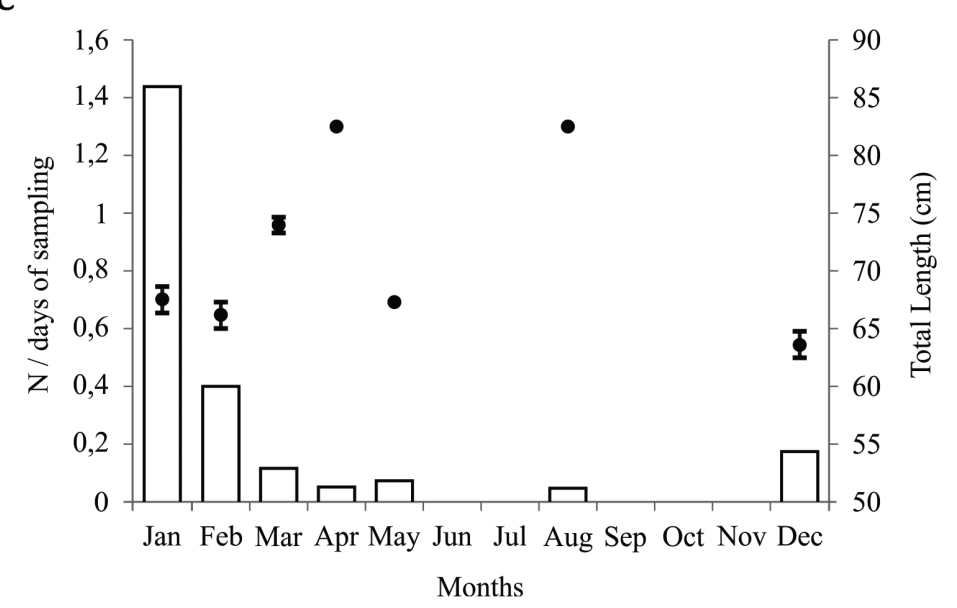

FIGURE 3 । Monthly mean daily abundance (number of individuals divided by days of sampling) and size (mean total length \pm standard deviation) of neonates (<90 cm TL) Blacktip Sharks, Carcharhinus limbatus, caught in Northeastern Brazil. A) Ceará; B) Rio Grande do Norte; C) Sergipe. White bars: monthly frequency; black dots with lines: mean TL \pm standard deviation. 
TABLE 1 I Uterine fecundity and size of embryos of Blacktip Sharks, Carcharhinus limbatus, captured in June 2004 in Rio Grande do Norte, Northeastern Brazil.

Pregnant

$\# 1$

$\# 2$

\#3
Mother size

195

193

199

\section{Litter size}

7

6

8
Embryos TL (cm) $\quad$ Mean TL ( \pm s.d.)

24.7-27

26.2-29

$22.2-24.5$
$25.64 \pm 0.81$

$27.80 \pm 1.02$

$23.42 \pm 0.83$

\section{DISCUSSION}

The peak of neonatal abundance found in December and January in the states of Ceará, Rio Grande do Norte and Sergipe, coincides with the end of spring and the beginning of summer. Additionally, it was possible to observe in the states of Ceará and Sergipe a gradual increase in the total length of the neonates over the months. In Rio Grande do Norte it was not possible to observe this pattern of gradual increase in the total length of the neonates because fishing landings were not monitored in January. In February, even with the monitoring of fisheries, no neonate or small juvenile was sampled, although according to local fishermen the capture of specimens with birth size is common in these months (Yokota, Lessa, 2006). The data presented here and what was found by Yokota, Lessa (2006) consistently support a well-defined parturition time in late springearly summer for C. limbatus in Northeastern Brazil. This same pattern of a well-marked parturition time in late spring-early summer was observed for the species in coastal waters from Paraná, Southern Brazil (Bornatowski, 2008).

The DTD of the embryos caught in June in Rio Grande do Norte indicates that the females were at the fifth month of gestation. Bornatowski (2008) also sampled three pregnant females, one in October carrying six embryos (51.5-53.7 cm TL), and two in November, carrying six and eight embryos measuring 55.2-56.1 and 55.6-57.6 cm TL, respectively. The DTD of these embryos was estimated at 279.66 and 297.22 days, for the embryos sampled in October and November, respectively. This indicates that the female caught in October was approximately at ninth month of gestation, and the females caught in November were approximately at tenth month of gestation. Considering a gestation of 11 months (Castro, 1996), these females from Northeastern and Southern Brazil, approximately $2600 \mathrm{~km}$ apart and with tropical and subtropical/ temperate climate, respectively, were both expected to give birth in December, despite the differences between them. Additionally, in December, another gravid female bearing seven embryos of unreported sizes was captured (Yokota, Lessa, 2006). Considering this pattern, it is probable that these were term embryos.

Thus, C. limbatus seem to present a well-defined parturition time in late spring-early summer in Southwestern Atlantic. The same pattern is found for the populations of the Southeastern United States (Castro, 1996); Gulf of Mexico (Baremore, Passerotti, 2013; here the birthing period occurred subtly earlier in spring) and the western and northern coasts of Africa (Capapé et al., 2004). Therefore, it is possible that this pattern of birth is predominant throughout the overall distribution of the species.

Carcharhinus limbatus is recognized for making use of distinct coastal nurseries (Castro, 1996; Carlson, 2002; Heupel, Hueter, 2002; Hueter, Tyminski, 2002; Heupel 
et al., 2004; Harry et al., 2012), and it seems evident the species is making use of regions of the Brazilian coast as nursery grounds in the spring-summer, although the criteria defined by Heupel et al. (2007), for an area to be considered a shark nursery, has not been tested. C. limbatus nursery grounds are generally "protected nurseries", located in areas that would theoretically be geographically protected from predators (Heupel, Hueter, 2002; Keeney et al., 2003; Heupel et al., 2004; Heupel, Simpfendorfer, 2005; Keeney et al., 2005; but also see Heupel et al., 2007). However, neonates and young-of-the-year from Brazil were sampled in unprotected open beaches, although the young were restricted to shallower waters (present study; Yokota, Lessa, 2006; Bornatowski, 2008). Future studies could indicate whether this is related to different life history components employed by different populations. For example, species from the Northwestern Atlantic could present a lower fecundity due to juveniles theoretically more protected, while populations from Southwestern Atlantic would compensate for the use of unprotected nurseries with a higher fecundity or growth rate. Although data are scarce for Southwestern Atlantic, the mean fecundity was 6.8 embryos (range: 6 to 8; based on 6 pregnant females analyzed by Yokota, Lessa, 2006 and Bornatowski, 2008), notably higher than the fertility calculated by Castro 1996 (3.85 embryos, based on 38 pregnant females from a protected nursery area).

Studies indicate that juveniles of C. limbatus remain in the nursery grounds of Northwest Atlantic for a period of two to three months (Castro, 1993; Heupel, Hueter, 2001), or even up to six months (Heupel et al., 2004). After the boom of birth in December and January, we observed a sharp drop in the abundance of the small juveniles until they disappear from the catches in March-April. This sharp decline in abundance may be due to a high mortality in this first stage of life, both natural and due to fishing. High mortality rates have been estimated for neonates of C. limbatus (Heupel, Simpfendorfer, 2002). Another possibility would be that juveniles in the Southwestern Atlantic tend to remain in the nursery grounds for less time, because they are theoretically unprotected nurseries.

Another issue to be addressed in future studies would be in relation to the extension of these probable nursery grounds in Brazil, checking the abundance of neonates and young-of-the-year in areas adjacent to the sampled areas. In this way, it would be possible to determine if $C$. limbatus would be using multiple areas of nursery grounds along Brazilian coast or if these points would constitute only parts of a wider pupping area. The answer to these questions, besides the elucidation of the complete reproductive cycle of C. limbatus in the Southwestern Atlantic, as well as the determination of its reproductive parameters, is fundamental for the creation of management measures aiming at the sustainable fishing and conservation of the species. The data presented here are preterit. Recent fisheries monitoring, as well as information obtained from local fishermen, have indicated a drastic decrease in the catch of newborns and small juveniles of $C$. limbatus in these regions, where they are caught by small-scale fisheries (see Meneses et al., 2005; Yokota, Lessa, 2006; Santander-Neto, Faria, 2020). Also, considering that sharks could not be considered as by catch mainly in Brazil (see Barreto et al., 2017), our lack of information about how industrial fisheries impact this species lead to major concern. 


\section{REFERENCES}

- Baremore IE, Passerotti MS. Reproduction of the blacktip shark in the Gulf of Mexico. Mar Coast Fish. 2013; 5(1):127-38. https://doi.org/10.1080/194251 20.2012.758204

- Barreto RR, Bornatowski H, Motta FS, Santander-Neto J, Vianna GMS, Lessa R. Rethinking use and trade of pelagic sharks from Brazil. Mar Policy. 2017; 85:114-22. https://doi.org/10.1016/j. marpol.2017.08.016

- Bornatowski H. A parturition and nursery area for Carcharhinus limbatus (Elasmobranchii, Carcharhinidae) off the coast of Paraná, Brazil. Braz J Oceanogr. 2008; 56(4):317-19. https://doi.org/10.1590/ S1679-87592008000400008

- Branstetter S. Age and growth estimates for blacktip, Carcharhinus limbatus, and spinner, C. brevipinna, sharks from the northwestern Gulf of Mexico. Copeia. 1987; 1987(4):964-74. Available from: https:// www.jstor.org/stable/1445560

- Branstetter S, Burgess GH. Commercial shark fishery observer program. Characterization and comparisons of the directed commercial shark fishery in the eastern Gulf of Mexico and off North Carolina through an observer program. Final Report, MARFIN Award NA47FF0008. Tampa; 1996.

- Branstetter S, Burgess GH. Commercial shark fishery observer program 1996. Gulf and South Atlantic Fisheries Development Foundation. Tampa; 1997.

- Burgess HG, Branstetter S. Carcharhinus limbatus. The IUCN Red List of Threatened Species. 2009:e.T3851A10124862. Available from: https://dx.doi.org/10.2305/IUCN. UK.2009-2.RLTS.T3851A10124862.en

- Capapé C, Seck AA, Diatta Y, Reynaud C, Hemida F, Zaquali J. Reproductive biology of the blacktip shark, Carcharhinus limbatus (Chondrichthyes: Carcharhinidae), off west and North African coasts. Cybium. 2004; 28(4):275-84.

- Carlson JK. Shark nurseries in the northeastern Gulf of Mexico. In: McCandless CT, Pratt HL-Jr, Kohler NE, editors. Shark nursery grounds of the Gulf of Mexico and east coast waters of the United States: an overview. Narragansett: An internal report to NOAA's Highly Migratory Species Office; 2002. p.165-82.
- Carlson JK, Sulikowski JR. Do differences in life history exist for blacktip sharks, Carcharhinus limbatus, from the United States South Atlantic Bight and Eastern Gulf of Mexico?. In: Carlson JK, Goldman KJ, editors. Special Issue: Age and growth of Chondrichthyan fishes: new methods, techniques and analysis. Developments in Environmental Biology of fishes. Vol. 25. Dordrecht: Springer. 2006; p.279-92. https://doi.org/10.1007/978-1-4020-5570-6_8

- Carneiro PMB, Salles R. Caracterização da pescaria com rede de emalhar derivante realizada no município de Fortaleza, estado do Ceará. Arq Cienc Mar. 2011; 44(1):69-80.

- Castro JI. The shark nursery of Bulls Bay, South Carolina, with a review of the shark nurseries of the southeastern coast of the United States. Environ Biol Fishes. 1993; 38(1-3):37-48. https://doi.org/10.1007/ BF00842902

- Castro JI. Biology of the Blacktip Shark, Carcharhinus limbatus, off the Southeastern United States. Bull Mar Sci. 1996; 59(3):508-22.

- Dudley SFJ, Cliff G. Sharks caught in the protective gill nets off Natal, South Africa. 7. The blacktip shark Carcharhinus limbatus (Valenciennes). Afr J Mar Sci. 1993; 13(1):237-54. https://doi. org/10.2989/025776193784287356

- Freitas MC. Caracterização da pesca artisanal praticada com jangadas sediadas na enseada do Mucuripe, município de Fortaleza-Ceará. [Monograph]. Fortaleza: Universidade Federal do Ceará; 2000.

- Hanfee F. Trade in sharks and shark products in India: a preliminary survey. New Delhi: Traffic India; 1997.

- Harry AV, Morgan JAT, Ovenden JR, Tobin AJ, Welch DJ, Simpfendorfer CA. Comparison of the reproductive ecology of two sympatric blacktip sharks (Carcharhinus limbatus and Carcharhinus tilstoni) off north-eastern Australia with species identification inferred from vertebral counts. J Fish Biol. 2012; 81(4):1225-33. https://doi.org/10.1111/ j.1095-8649.2012.03400.x 
- Heupel MR, Carlson JK, Simpfendorfer CA. Shark nursery areas: concepts, definition, characterization and assumptions. Mar Ecol Prog Ser. 2007; 337:287-97. http://doi.org/10.3354/ meps337287

- Heupel MR, Hueter RE. Use of an automated acoustic telemetry system to passively track juvenile blacktip shark movements. In: Silbert JR, Nielsen JL, editors. Electronic tagging and tracking in marine fisheries. Reviews: Methods and technologies in fish biology and fisheries, vol. 1. Dordrecht: Springer; 2001. p.217-36. https://doi.org/10.1007/978-94-017-14020_10

- Heupel MR, Hueter RE. Importance of prey density in relation to the movement patterns of juvenile blacktip sharks (Carcharhinus limbatus) within a coastal nursery area. Mar Freshw Res. 2002; 53(2):543-50. https://doi.org/10.1071/ MF01132

- Heupel MR, Simpfendorfer CA. Estimation of mortality of juvenile blacktip sharks, Carcharhinus limbatus, within a nursery area using telemetry data. Can J Fish Aquat Sci. 2002; 59(4):624-32. https:// doi.org/10.1139/f02-036

- Heupel MR, Simpfendorfer CA. Quantitative analysis of aggregation behavior in juvenile blacktip sharks. Mar Biol. 2005; 147(5):1239-49. https://doi. org/10.1007/s00227-005-0004-7

- Heupel MR, Simpfendorfer CA, Hueter RE. Estimation of shark home ranges using passive monitoring techniques. Environ Biol Fishes. 2004; 71(2):135-42. https://doi. org/10.1023/B:EBFI.0000045710.18997.f7

- Hueter RE, Tyminski JP. U.S. shark nursery research overview, Center for Shark Research, Mote Marine Laboratory 1991-2001.Mote Mar Lab Tech Rpt. 2002; 816:116-35.

- Keeney DB, Heist EJ. Worldwide phylogeography of the blacktip shark (Carcharhinus limbatus) inferred from mitochondrial DNA reveals isolation of western Atlantic populations coupled with recent Pacific dispersal. Mol Ecol. 2006; 15(12):3669-79. https://doi.org/10.1111/ j.1365-294X.2006.03036.x
- Keeney DB, Heupel MR, Hueter RE, Heist EJ. Genetic heterogeneity among blacktip shark, Carcharhinus limbatus, continental nurseries along the U.S. Atlantic and Gulf of Mexico. Mar Biol. 2003; 143(6):1039-46. https://doi.org/10.1007/s00227-003-1166-9

- Keeney DB, Heupel MR, Hueter RE, Heist EJ. Microsatellite and mitochondrial DNA analyses of the genetic structure of blacktip shark (Carcharhinus limbatus) nurseries in the northwestern Atlantic, Gulf of Mexico, and Caribbean Sea. Mol Ecol. 2005; 14(7):1911-23. https://doi. org/10.1111/j.1365-294X.2005.02549.x

- Killam KA, Parsons GR. Age and growth of the blacktip shark, Carcharhinus limbatus, near Tampa Bay, Florida. Fish Bull. 1989; 87(4):845-57.

- Meneses TS, Santos FN, Pereira CW. Fauna de Elasmobrânquios do litoral do estado de Sergipe, Brasil. Arq Cienc Mar. 2005; 38(1-2):79-83. https://doi. org/10.32360/acmar.v38i1-2.6396

- Santander-Neto J, Faria VV. Sharks and rays caught by a small-scale fisheries in the western equatorial Atlantic. J Appl Ichthyol. 2020; 00:1-4. https://doi. org/10.1111/jai.14103

- Sodré D, Rodrigues-Filho LFS, Souza RFC, Rêgo PS, Schneider H, Sampaio I, Vallinoto M. Inclusion of South American samples reveals new population structuring of the blacktip shark (Carcharhinus limbatus) in the western Atlantic. Genet Mol Biol. 2012; 35(4):752-60. https://doi.org/10.1590/S141547572012005000062

- Vaingast S. Im2graph [Software]; 2014.

- Yokota L, Lessa RP. A nursery area for sharks and rays in Northeastern Brazil. Environ Biol Fishes. 2006; 75(3):349-60. https://doi.org/10.1007/s10641-006-0038-9 


\section{Neotropical Ichthyology}

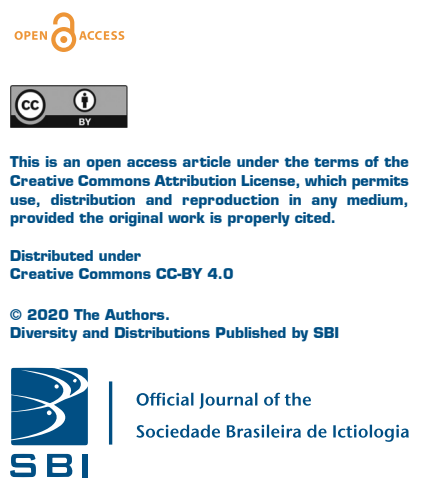

\section{AUTHOR'S CONTRIBUTION}

Jones Santander-Neto: Conceptualization, Data curation, Formal analysis, Methodology, Supervision, Writing-original draft, Writing-review \& editing.

Leandro Yokota: Data curation, Formal analysis, Methodology, Visualization, Writing-review \& editing. Thiago Silveira de Meneses: Data curation, Methodology, Writing-review \& editing.

ETHICAL STATEMENT

Not applicable.

\section{COMPETING INTERESTS}

The authors declare no competing interests.

HOW TO CITE THIS ARTICLE

- Santander-Neto J, Yokota L, Meneses TS. Parturition time for the Blacktip shark, Carcharhinus limbatus (Carcharhiniformes: Carcharhinidae), in Southwestern Atlantic. Neotrop Ichthyol. 2020; 18(3):e200029. https://doi.org/10.1590/1982-0224-2020-0029 